\title{
SKRINING FITOKIMIA DAN AKTIVITAS ANTIBAKTERI EKSTRAK KULIT BATANG (Eusideroxylon zwageri) TERHADAP Escherichia coli DAN Salmonella typhi
}

(Phytochemicals screening and antibacterial activities of Eusideroxylon zwageri wood bark extract against Escherichia coli and Salmonella typhi)

\author{
Hana Wila, Fathul Yusro, Yeni Mariani \\ Fakultas Kehutanan Universitas Tanjungpura Jalan Imam Bonjol Pontianak 78124 \\ Email: hana.hana.hh770@gmail.com
}

\begin{abstract}
Diarrhea and typhoid fever are diseases commonly suffered by people in Indonesia, and bacteria such as Escherichia coli (diarrhea) and Salmonella typhi (typhoid fever) are one of those diseases causative agents. Various plants are potentially used as anti-bacterial including ulin (Eusideroxylon zwageri). The aims of this study were to analysis the yield and potential secondary metabolite content in ethanol extract of E. zwageri, and determine the optimal concentration in inhibits the growth of bacteria E. coli and S. typhi. The methods used in this study were measure the moisture content of E. zwageri wood bark powder, extraction with ethanol solvent, measure the yield percentage, qualitative of phytochemical analysis, and antibacterial assays. The results showed that the yield of ethanol extract of E. zwageri is $21,63 \%$ with 7,6\% of moisture content. The extract positively contained alkaloids, flavonoids, tannins, saponins, phenolics and terpenoids. The optimum concentration in inhibits the growth of bacteria E. coli is $200 \mathrm{mg} / \mathrm{ml}$ and categorized as very strong inhibition response, and 15 $\mathrm{mg} / \mathrm{ml}$ is concentration used in inhibits the S. typhi and categorized as strong inhibition response.

Keywords: Antibacterial activity, Escherichia coli, Eusideroxylon zwageri, phytochemical screening, Salmonella typhi.
\end{abstract}

\section{PENDAHULUAN}

Indonesia sebagai negara berkembang tidak terlepas dari beragam masalah kesehatan, salah satunya adalah penyakit yang terkait dengan sanitasi yaitu diare. Diare merupakan suatu kondisi dimana frekuensi buang air besar lebih dari tiga kali dalam sehari dengan bentuk feces yang lembek ataupun cair (Kemenkes, 2011). Penyakit ini merupakan salah satu penyebab kematian utama pada balita (WHO, 2009; Kemenkes RI, 2011), dengan tingkat insidensi sebesar 3,5\% dan prevalensi sebesar 7\% (Kemenkes RI, 2011). Penyakit lain yang mempunyai gejala berupa diare disertai demam, perut kembung, badan terasa lemah, mual, pusing dan muntah adalah demam tifus (tifoid) (Pelczar dan Chan, 2005). Feces yang keluar dikarenakan diare akibat demam tifus biasanya disertai darah dan terjadi pada minggu kedua selama periode sakit ataupun penyembuhan (WHO, 2009; Pelczar dan Chan, 2005). Penyebab utama penyakit diare dan demam tifoid adalah bakteri pathogen. Salah satu jenis bakteri penyebab diare adalah Escherichia coli dan penyebab demam tifus adalah Salmonella typhi (Sari et al. 2015).

Pengobatan tradisional telah digunakan oleh masyarakat untuk mengatasi penyakit diare dan demam tifus. Dipilihnya pengobatan tradisional karena bahan bakunya yang tersedia dilingkungan 
sekitar, harga lebih murah dan memiliki efek samping yang lebih rendah jika dibandingkan dengan obat modern (Wasito, 2011).

Kalimantan Barat memiliki beragam jenis tumbuhan obat, dan saat ini telah terdata sebanyak 208 species yang digunakan untuk perawatan kesehatan maupun untuk pengobatan terhadap penyakit (Yusro et al. 2013, Yusro et al. 2014). Salah satu diantaranya adalah ulin (Eusideroxylon zwageri) yang termasuk ke dalam famili Lauraceae (Heyne, 1987) yaitu sebagai obat sakit perut (Mariani et al. 2016), sakit kuning (liver) dan bengkak (Yusro et al. 2013).

Darussalam (2016) melaporkan bahwa ekstrak kayu ulin mengandung alkaloid, flavonoid, triterpenoid, tanin, saponin, dan potensial sebagai obat diare yang tunjukkan dengan aktivitasnya dalam menghambat pertumbuhan bakteri Staphylococcus aureus. Ekstrak daun ulin telah terbukti mampu mengatasi inflamasi atau peradangan pada usus (Mariani et al. 2016). Berdasarkan hasil-hasil penelitian diatas maka ulin berpotensi untuk dijadikan sebagai obat alternatif untuk antibakteri. Sejauh ini penelitian yang telah dilakukan adalah terhadap bagian kayu dan daun E. zwageri namun belum ada penelitian yang dilakukan pada bagian kulit batang $E$. zwageri terhadap bakteri $E$. coli dan S. typhi.

Hasil penelitian pendahuluan menunjukkan bahwa ekstrak etanol kulit batang E. zwageri dengan konsentrasi 10 $\mathrm{mg} / \mathrm{ml}$ mampu menghambat bakteri $S$. typhi sebesar $18 \mathrm{~mm}$, dan pada konsentrasi $100 \mathrm{mg} / \mathrm{ml}$ mampu menghambat pertumbuhan bakteri E. coli sebesar 9,5 mm. Dengan adanya potensi dari kulit batang E. zwageri dalam menghambat pertumbuhan E. coli dan S. typhi maka perlu dilakukan penelitian untuk mengetahui konsentrasi optimum dalam menghambat pertumbuhan bakteri tersebut dan golongan senyawa bioaktif potensial yang terkandung dalam ekstrak etanol kulit batang E. zwageri. Penelitian ini bertujuan untuk menganalisis rendemen dan golongan senyawa bioaktif potensial yang terkandung dalam ekstrak etanol kulit batang E. zwageri serta konsentrasi optimumnya dalam menghambat pertumbuhan bakteri E. coli dan S. typhi.

\section{METODOLOGI PENELITIAN}

\section{Alat dan Bahan}

Penelitian ini dilakukan di Bagian Laboratorium Wood Work Shop, Laboratorium Teknologi Kayu Fakultas Kehutanan Universitas Tanjungpura, Laboratorium Kimia Fakultas Matematika dan Ilmu Pengetahuan Alam Universitas Tanjungpura, dan Unit Laboratorium Kesehatan Provinsi Kalimantan Barat. Alat yang digunakan antara lain hammer mill, mesh screen, shaker, rotary evaporator, autoclave, mikroskop digital, mikropipet, dan inkubator. Bahan-bahan yang digunakan adalah kulit batang E.zwageri yang diperoleh dari Desa Bumi Emas Kecamatan Bengkayang Kabupaten Bengkayang, isolat bakteri E.coli dan S.typhi, etanol $96 \%, \mathrm{H}_{2} \mathrm{SO}_{4} 2 \mathrm{~N}$, asam asetat anhidrat, asam sulfat pekat, dietil eter, $\mathrm{HCl}$ pekat, serbuk magnesium, metanol, $\mathrm{NaOH}$ $10 \%, \mathrm{HCl} 2 \mathrm{~N}, \mathrm{FeCl}_{3} 1 \%$, pereaksi meyer, pereaksi dragendorff, dan pereaksi wagner, kertas cakram, media PCA (Plat Count Agar), etanol, dan tetracyline.

\section{Prosedur Penelitian}


Persiapan Sampel

Kulit batang E.zwageri pada ketinggian diatas $50 \mathrm{~cm}$ diambil dengan menggunakan pisau tanpa melukai kambiumnya. Bagian kulit yang diambil adalah kulit bagian dalam yang berwarna merah kecoklatan. Kulit kayu yang diperoleh selanjutnya dibersihkan dari kulit luar serta benda asing (kotoran atau lumut), dijemur hingga kering dan dipotong kecil dengan ukuran $\pm 2 \mathrm{~cm}$. Potongan kulit tersebut selanjutnya dibuat serbuk mengunakan hammer mill dan hasilnya disaring dengan menggunakan saringan lolos 40 mesh tertahan 60 mesh.

\section{Pengukuran Kadar Air}

Kulit batang E.zwageri dengan berat 2 gram di oven dengan suhu $103 \pm 2^{\circ} \mathrm{C}$ selama 24 jam. Setelah itu, serbuk didinginkan didalam desikator selama 15 menit dan ditimbang perubahan beratnya. Proses pengovenan dilakukan secara berulang seperti prosedur awal hingga diperoleh berat yang konstan. Kadar air dihitung dengan persamaan: (Haygreen dan Bowyer, 1996; Manuhuwa, 2007)

$\%$ Kadar air $=\frac{a-b}{b} \times 100 \%$

Dimana :

$a=$ berat serbuk sebelum dikeringkan (g)

$b=$ berat serbuk setelah dikeringkan (g)

Ekstraksi

Pengukuran Rendemen Ekstrak

Serbuk kulit batang E. zwageri dengan berat 1 gram diekstraksi dengan menambahkan $50 \mathrm{ml}$ pelarut etanol. Proses ekstraksi dilakukan selama 24 jam dan secara kontinyu dikocok menggunakan shaker. Setelah itu, ekstrak yang diperoleh disaring dan residu yang diperoleh selanjutnya diekstraksi kembali seperti perlakuan awal hingga diperoleh ekstrak yang jernih. Filtrat yang diperoleh selanjutnya diuapkan dengan menggunakan waterbath pada suhu $60^{\circ} \mathrm{C}$ hingga diperoleh ekstrak kering. Rendemen ekstrak diukur dengan persamaan (Rahmah et al. 2014):

$\%$ Ekstrak $=\frac{a}{(1-x) b} \times 100 \%$

Dimana:

$a=$ berat ekstrak (g)

$b=$ berat serbuk $(\mathrm{g})$

$x=$ kadar air

Penyiapan Ekstrak untuk Sampel Pengujian

Serbuk kulit batang E. zwageri dengan berat 200 gram diekstraksi dengan menambahkan $1000 \mathrm{ml}$ pelarut etanol (perbandingan 1:5). Proses ekstraksi dilakukan selama 24 jam dan secara kontinyu dikocok menggunakan shaker. Setelah itu, ekstrak yang diperoleh disaring dan residu yang diperoleh selanjutnya diekstraksi kembali seperti perlakuan awal sebanyak 4 kali. Filtrat yang diperoleh selanjutnya diuapkan menggunakan rotary evaporator pada suhu $59-60^{\circ} \mathrm{C}$ hingga diperoleh ekstrak pekat dan selanjutnya ekstrak tersebut dikeringkan menggunakan waterbath pada suhu $60^{\circ} \mathrm{C}$ hingga diperoleh ekstrak kering. Hasil ekstrak tersebut digunakan sebagai bahan untuk pengujian fitokimia dan aktivitas anti bakteri.

\section{Skrining Fitokimia}

Pengujian kualitatif fitokimia ekstrak etanol kulit batang E. zwageri mengacu pada Harborne (1996) dengan sedikit modifikasi. Ekstrak kering dengan berat 1 gram diencerkan dengan pelarut metanol (10 ml) (Mailuhu et al. 2017) dan selanjutnya dilakukan pengujian alkaloid, 
flavonoid, steroid, triterpenoid, saponin dan fenolik.

\section{Uji Alkaloid}

Sebanyak 3 buah tabung reaksi dimasukkan $1 \mathrm{ml}$ ekstrak dan ditambahkan 10 tetes $\mathrm{H}_{2} \mathrm{SO}_{4} 2 \mathrm{~N}$. Selanjutnya pereaksi dragendorff ditambahkan pada tabung pertama, pereaksi wagner pada tabung kedua, dan pereaksi meyer pada tabung ketiga. Apabila pada tabung pertama terbentuk endapan berwarna merah jingga, endapan berwarna coklat pada tabung kedua, dan endapan berwarna putih pada tabung ketiga maka ekstrak E. zwageri positif mengandung alkaloid.

Uji Flavonoid

\section{a. $\mathrm{HCl}$ Pekat dan Magnesium (Mg)}

Sebanyak 2 tetes $\mathrm{HCl}$ pekat ditambahkan pada tabung reaksi yang telah berisi $1 \mathrm{ml}$ ekstrak dan dikocok kuat. Selanjutnya, ditambahkan juga serbuk $\mathrm{Mg}$ dan dikocok kembali. Apabila terbentuk buih/busa dalam intensitas besar serta terjadi perubahan warna menjadi jingga maka ekstrak E. zwageri positif mengandung flavonoid

\section{b. $\mathrm{H}_{2} \mathrm{SO}_{4}$}

$\begin{array}{lllll}\text { Sebanyak } & 2 & \text { tetes } & \mathrm{H}_{2} \mathrm{SO}_{4} & 2 \mathrm{~N}\end{array}$ ditambahkan pada tabung reaksi yang telah berisi $1 \mathrm{ml}$ ekstrak dan dikocok kuat. Apabila terjadi perubahan warna ekstrak E. zwageri menjadi kuning, merah, hijau atau coklat, maka positif mengandung flavonoid.

c. $\mathrm{NaOH} 10 \%$

Sebanyak 2 tetes $\mathrm{NaOH} \quad 10 \%$ ditambahkan pada tabung reaksi yang telah berisi $1 \mathrm{ml}$ ekstrak dan dikocok kuat. Apabila terjadi perubahan warna ekstrak E. zwageri menjadi kuning, merah, atau coklat, maka positif mengandung flavonoid.

Uji Tanin

Sebanyak 10 tetes $\mathrm{FeCl} \quad 1 \%$ ditambahkan pada tabung reaksi yang telah berisi $1 \mathrm{ml}$ ekstrak. Apabila terjadi perubahan warna ekstrak E. zwageri menjadi hijau kehitaman atau biru kehitaman, maka positif mengandung flavonoid.

\section{Uji Triterpenoid dan Steroid}

Ekstrak E. zwageri diteteskan pada 3 buah lubang di plat tetes, dimana pada lubang pertama sebagai kontrol/standar, kedua untuk uji triterpenoid dan ketiga untuk uji steroid. Biarkan ekstrak tersebut hingga mengering, dan selanjutnya ditambahkan 1 tetes $\mathrm{H}_{2} \mathrm{SO}_{4}$ pekat, 1 tetes asam asetat anhidrat dan 2 tetes dietil eter. Apabila terjadi perubahan warna ekstrak E. zwageri menjadi merah, biru, ungu atau coklat maka positif mengandung terpenoid (triterpenoid), dan apabila menjadi warna biru atau hijau maka positif mengandung steroid.

\section{Uji Saponin}

Sebanyak $5 \mathrm{ml}$ air panas ditambahkan pada tabung reaksi yang telah berisi $1 \mathrm{ml}$ ekstrak dan dikocok selama 1 menit. Selanjutnya, ditambahkan juga $\mathrm{HCl} 2 \mathrm{~N}$ sebanyak 2 tetes dan dikocok kembali. Apabila terbentuk buih/busa dalam intensitas besar dan konsisten selama 10 menit maka ekstrak E. zwageri positif mengandung saponin.

\section{Uji Fenolik}

Sebanyak 2-3 tetes besi (III) klorida $\left(\mathrm{FeCl}_{3}\right) \quad 1 \%$ ditambahkan pada tabung reaksi yang telah berisi $1 \mathrm{ml}$ ekstrak. Apabila terjadi perubahan warna ekstrak 
E. zwageri menjadi warna biru kehitaman maka positif mengandung fenolik.

\section{Uji Aktivitas Antibakteri}

Sebanyak $20 \mu 1$ larutan ekstrak etanol kulit batang E.zwageri dengan konsentrasi 1,5,10 dan $15 \mathrm{mg} / \mathrm{ml}$ untuk bakteri S.typhi; 50, 100, 150 dan $200 \mathrm{mg} / \mathrm{ml}$ untuk bakteri E.coli dan antibiotik $(30 \mu \mathrm{g} / \mathrm{ml})$ diteteskan menggunakan mikropipet pada kertas cakram berdiameter $5 \mathrm{~mm}$. Kertas cakram tersebut kemudian diletakkan pada biakan bakteri dalam cawan petri menggunakan pinset steril. Biakan bakteri tersebut kemudian diinkubasi selama 24 jam pada suhu $35^{\circ} \mathrm{C}$. Zona hambat $(\mathrm{mm})$ yang terbentuk menunjukkan adanya aktivitas antibakteri. Respon ekstrak dalam menghambat pertumbuhan bakteri dapat diklasifikasikan kedalam beberapa tingkatan (Anita et al. 2014), yaitu:

Tabel 1. Klasifikasi Respon Hambatan Pertumbuhan Bakteri (Classification of inhibition response)

\begin{tabular}{cc}
\hline Zona hambat $(\mathbf{m m})$ & Respon hambatan \\
\hline$\geq 20 \mathrm{~mm}$ & Sangat Kuat \\
$11-19 \mathrm{~mm}$ & Kuat \\
$5-10 \mathrm{~mm}$ & Sedang \\
$<5 \mathrm{~mm}$ & Lemah \\
\hline
\end{tabular}

Data zona hambat yang diperoleh kemudian dilakukan analisis statistik dan uji beda nyata jujur (BNJ) menggunakan SPSS 16 untuk melihat pengaruh perlakuan terhadap aktivitasnya dalam menghambat pertumbuhan bakteri.

\section{HASIL DAN PEMBAHASAN}

\section{Rendemen Ekstrak E. zwageri}

Rendemen ekstrak etanol kulit batang E. zwageri yang diperoleh dari hasil penelitian ini sebesar 21,63\% (kadar air serbuk 7,6\%). Hasil ini lebih tinggi jika dibandingkan dengan bagian lain dari tanaman E. zwageri dimana pada bagian daun memiliki rendemen ekstrak berkisar antara 4,33-8,99\% (Mariani et al. 2016). Mengacu pada pengelompokkan/kelas komponen kimia kayu Indonesia (Anonim, 1976), rendemen ekstrak etanol kulit batang E. zwageri tergolong tinggi yaitu diatas $4 \%$.

Tingginya rendemen ekstrak $E$. zwageri diduga karena pemilihan bagian tanaman dalam hal ini adalah kulit kayu dan penggunaan pelarut etanol. Setiap bagian tanaman memiliki kadar zat ekstraktif yang berbeda dan kadar zat ekstraktif yang terdapat pada kulit kayu lebih tinggi dengan bagian lain dari suatu tanaman (Sjostrom, 1995). Pelarut etanol merupakan pelarut polar yang memiliki kemampuan yang baik untuk berpenetrasi kedalam membran sel, sehingga komponen-komponen endoseluler dapat diperoleh secara maksimal yang pada akhirnya menyebabkan rendemen ekstrak menjadi tinggi (Silva, 1998). Beberapa golongan senyawa yang dapat larut bersama dengan pelarut etanol antara lain tanin, saponin, flavonoid, kuinon, minyak, lemak, lilin, alkaloid, phenol, aglikon dan glikosida (Hougton dan Raman, 1998; Filho, 2006; Yusro, 2010). Senyawasenyawa tersebut sangat potensial sebagai antibakteri.

\section{Skrining Fitokimia}

Golongan senyawa bioaktif yang terdapat pada suatu tanaman dapat diketahui dengan melakukan skrining fitokimia. Hasil penelitian menunjukkan 
bahwa ekstrak kulit batang E. zwageri senyawa bioaktif yang secara jelas tertera positif mengandung beberapa golongan pada Tabel 2.

Tabel 2. Hasil skrining fitokimia ekstrak kulit batang E. zwageri (Results of phytochemical screening analysis of wood bark E. zwageri extract)

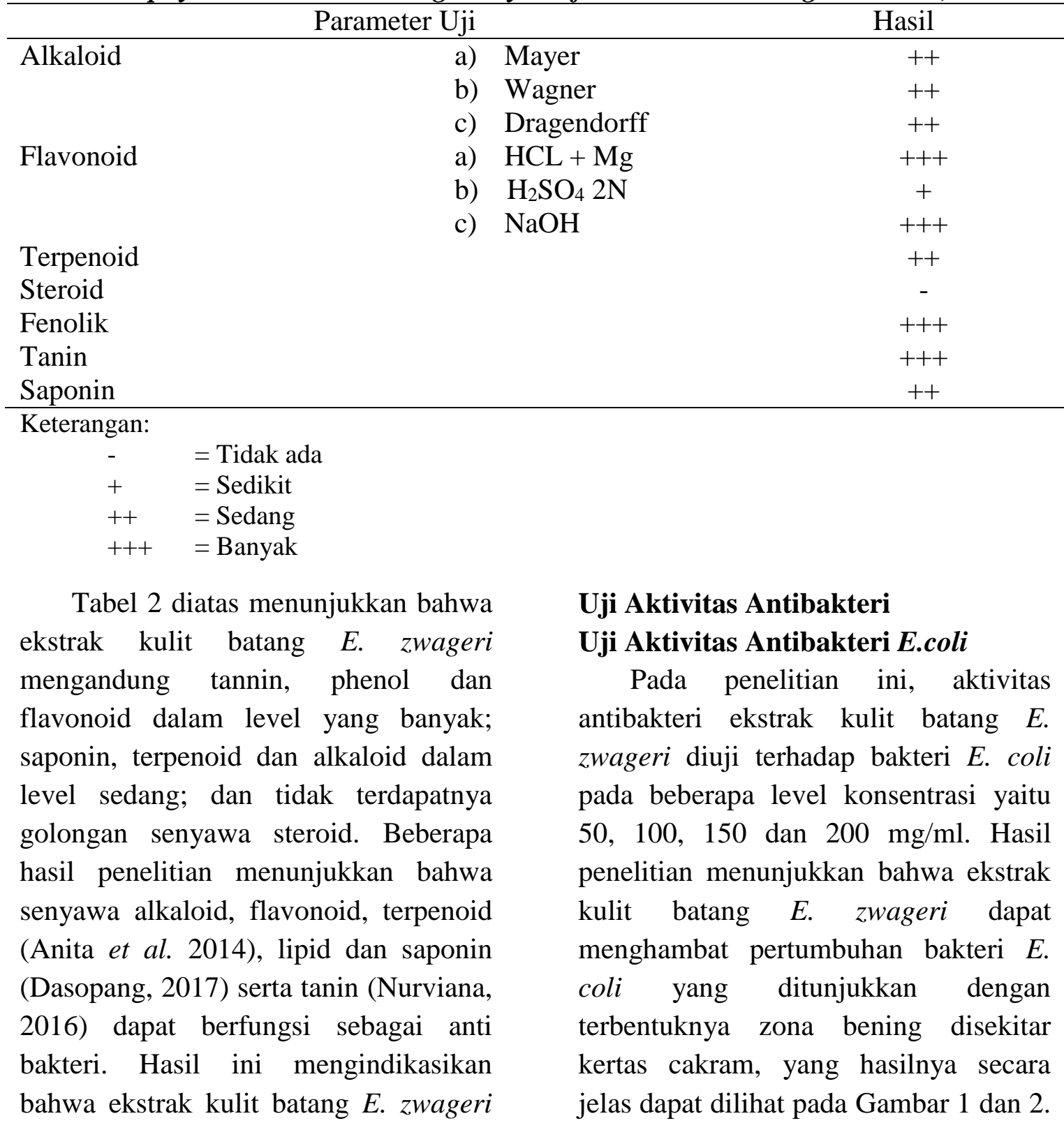
memiliki golongan senyawa bioaktif yang potensial sebagai antibakteri. 


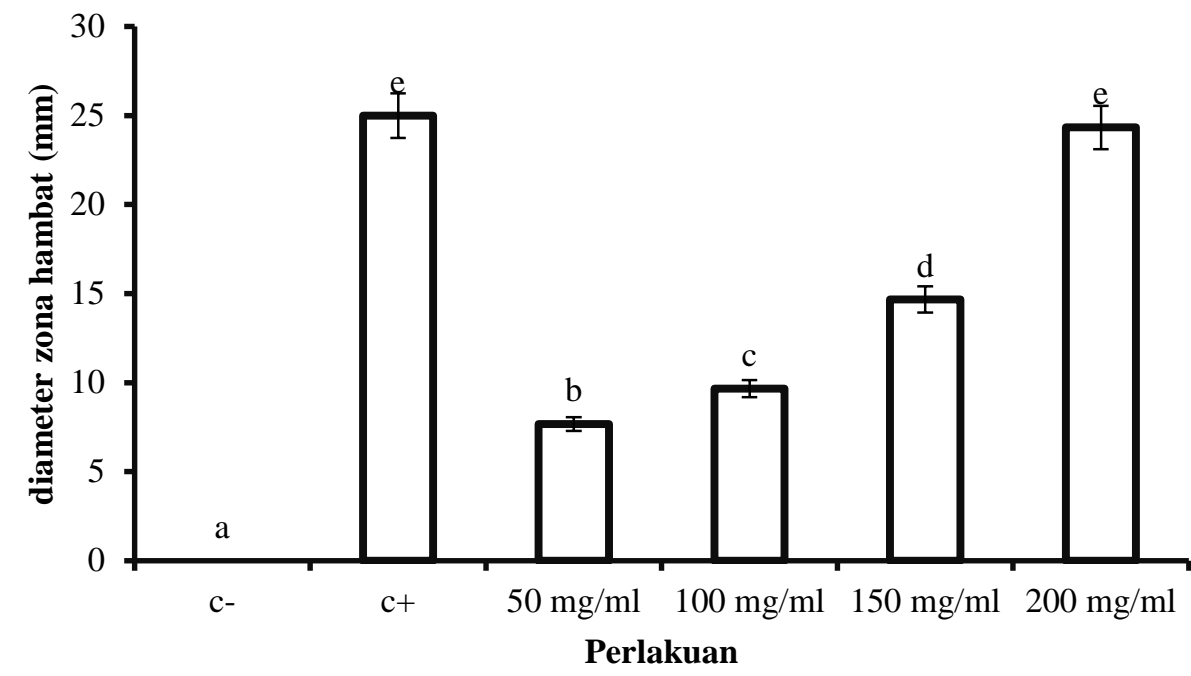

Gambar 1. Grafik zona hambat ekstrak kulit batang E. zwageri terhadap pertumbuhan $E$. coli. (Graph of inhibition zone of wood bark extract of E. zwageri againts the growth of E. coli)

Keterangan:

c- $\quad=$ kontrol negatif

$\mathrm{c}+\quad=$ kontrol positif

$\mathrm{a}, \mathrm{b}, \mathrm{c}, \mathrm{d}, \mathrm{e}=$ angka yang ditandai dengan huruf yang tidak sama menunjukkan pengaruh berbeda nyata atau signifikan pada taraf kepercayaan $99 \%$.

Dari Gambar 1 terlihat bahwa konsentrasi $200 \mathrm{mg} / \mathrm{ml}$ memiliki daya hambat lebih tinggi yang ditunjukkan dengan zona hambatnya sebesar 24,33 $\mathrm{mm}$, diikuti oleh konsentrasi $150 \mathrm{mg} / \mathrm{ml}$ sebesar $14,67 \mathrm{~mm}, 100 \mathrm{mg} / \mathrm{ml}$ sebesar 9,67 mm, $50 \mathrm{mg} / \mathrm{ml}$ sebesar 7,67 mm, sedangkan untuk kontrol negatif (pelarut etanol) tidak menunjukkan daya hambat terhadap pertumbuhan E. coli. Jika dibandingkan dengan obat antibiotik (tetracycline) sebagai kontrol positif yang memiliki daya hambat sebesar $25 \mathrm{~mm}$, maka konsentrasi 50, 100 dan $150 \mathrm{mg} / \mathrm{ml}$ ekstrak kulit batang E. zwageri mempunyai daya hambat yang rendah.

Konsentrasi 50, 100, 150 dan 200 $\mathrm{mg} / \mathrm{ml}$, serta kontrol positif memberikan pengaruh yang signifikan atau berbeda nyata dalam menghambat pertumbuhan E. coli jika dibandingkan dengan kontrol negatif. Hasil respon hambatan pada zona hambat pertumbuhan E. coli menunjukkan bahwa konsentrasi 200 $\mathrm{mg} / \mathrm{ml}$ memiliki respon hambatan sangat kuat, diikuti $150 \mathrm{mg} / \mathrm{ml}$ memiliki respon hambatan kuat, $100 \mathrm{mg} / \mathrm{ml}$ dan $50 \mathrm{mg} / \mathrm{ml}$ memiliki respon hambatan sedang.

Level konsentrasi optimum ekstrak kulit batang E. zwageri adalah yang memiliki respon hambatan kuat atau sangat kuat terhadap pertumbuhan E.coli yaitu pada konsentrasi $150 \mathrm{mg} / \mathrm{ml}$ dan $200 \mathrm{mg} / \mathrm{ml}$. Pada konsentrasi 200 $\mathrm{mg} / \mathrm{ml}$, zona hambat yang terbentuk sudah setara dengan antibiotik 
(tetracycline) yang ditunjukkan dengan tidak adanya perbedaan yang signifikan diantara keduanya. Hal ini menunjukkan bahwa ekstrak tersebut pada konsentrasi $200 \mathrm{mg} / \mathrm{ml}$ memiliki kemampuan yang sebanding dengan tetracycline dalam menghambat pertumbuhan bakteri E.coli. Tetracycline merupakan golongan obat antibiotik yang memiliki spektrum yang luas dan sensitif terhadap bakteri gram negatif seperti E.coli. Tetracycline akan terakumulasi didalam sel bakteri dalam bentuk ionik ketika melewati membrane sitoplasma, sehingga dapat menghambat sistesis protein dan pada akhirnya menyebabkan kematian sel bakteri (Pratiwi, 2008).

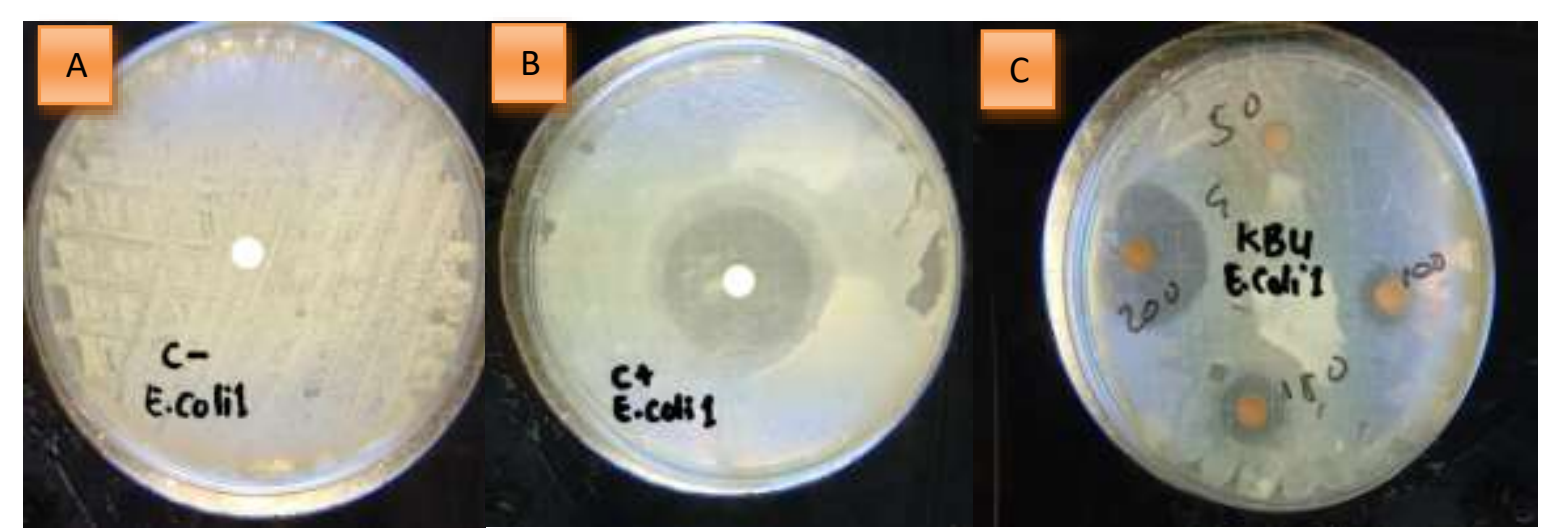

Gambar 2. Zona hambat terhadap bakteri E. coli: A. Kontrol negatif; B. Kontrol positif; C. ekstrak kulit batang E. zwageri (50,100,150, dan $200 \mathrm{mg} / \mathrm{ml}$ ) (Diameter of inhibition zone on bacteria E. coli: A. Negative control; B. Positive control; C. E. zwageri wood bark extract concentration levels (50, 100, 150, and 200 $m g / m l)$

\section{Uji Aktivitas Antibakteri S.typhi}

Pada penelitian ini, aktivitas antibakteri ekstrak etanol kulit batang $E$. zwageri diuji terhadap bakteri S. typhi pada beberapa level konsentrasi yaitu 1 , 5, 10 dan $15 \mathrm{mg} / \mathrm{ml}$. Hasil penelitian menunjukkan bahwa ekstrak kulit batang E. zwageri dapat menghambat pertumbuhan bakteri $S$. typhi yang ditunjukkan dengan terbentuknya zona bening disekitar kertas cakram, yang hasilnya secara jelas dapat dilihat pada Gambar 3 dan 4. 


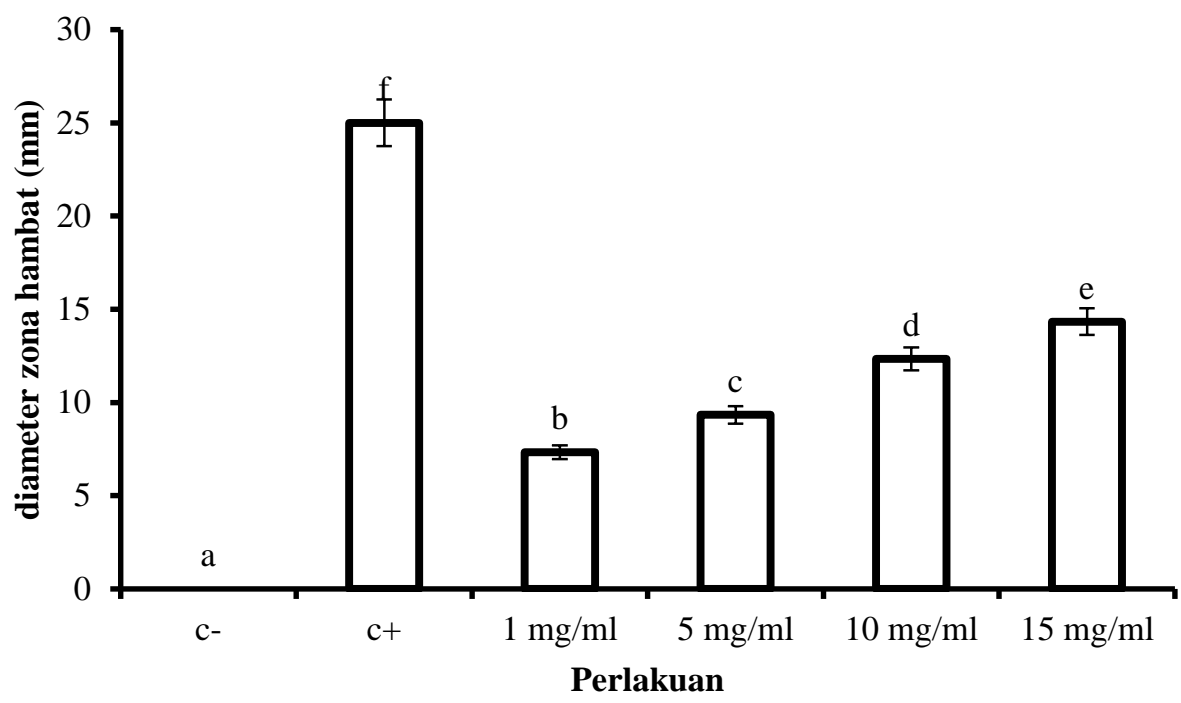

Gambar 3. Grafik zona hambat ekstrak kulit batang E. zwageri terhadap pertumbuhan $S$. typhi. (Graph of inhibition zone of wood bark extract of E. zwageri againts the growth of S. typhi).

Keterangan:

c- $\quad=$ kontrol negatif

$\mathrm{c}+\quad=$ kontrol positif

$\mathrm{a}, \mathrm{b}, \mathrm{c}, \mathrm{d}, \mathrm{e}=$ angka yang ditandai dengan huruf yang tidak sama menunjukkan pengaruh berbeda nyata atau signifikan pada taraf kepercayaan $99 \%$.
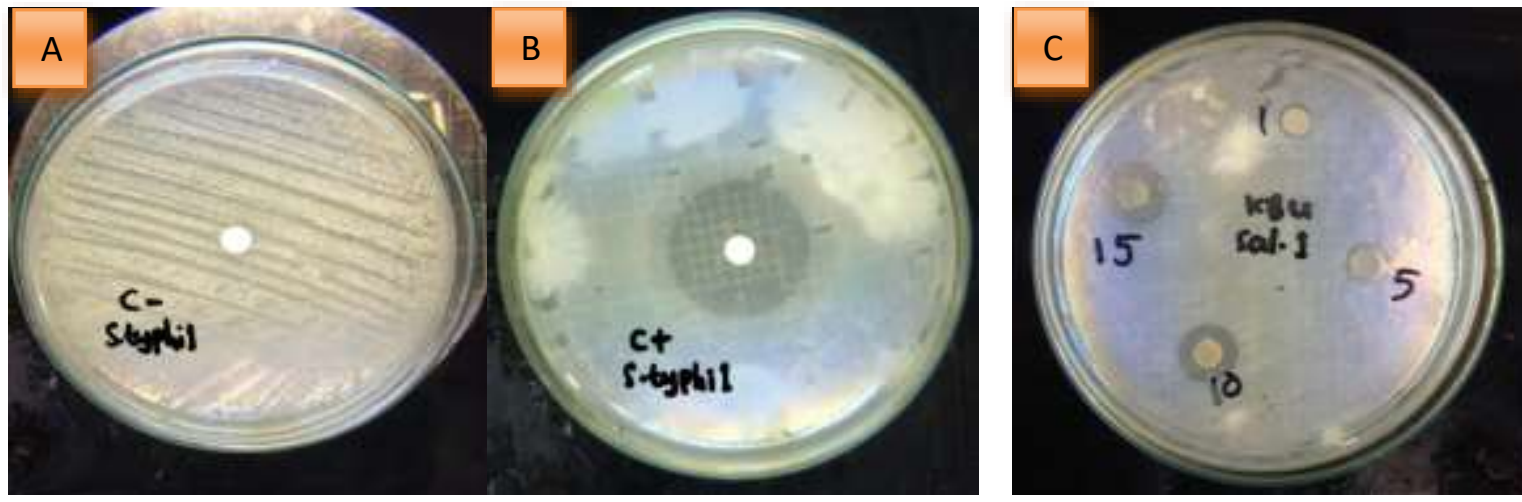

Gambar 4. Zona hambat terhadap bakteri S. typhi: A. Kontrol negatif; B. Kontrol positif; C. Ekstrak kulit batang E. zwageri $(1,5,10$ dan $15 \mathrm{mg} / \mathrm{ml})$. (Diameter of inhibition zone on bacteria S. typhi; A. Negative control; B. Positive control; C. E. zwageri wood bark extract concentration levels $(1,5,10$, and 15 $\mathrm{mg} / \mathrm{ml})$.

Gambar 3 dan 4 menunjukkan bahwa ekstrak kulit batang E. zwageri dapat menghambat pertumbuhan S.typhi dimana pada konsentrasi $15 \mathrm{mg} / \mathrm{ml}$ memiliki daya hambat lebih tinggi, yang ditunjukkan dengan zona hambatnya sebesar 14,33

$\mathrm{mm}$, diikuti oleh konsentrasi $10 \mathrm{mg} / \mathrm{ml}$ sebesar 12,33 mm, $5 \mathrm{mg} / \mathrm{ml}$ sebesar 9,33 $\mathrm{mm}, 1 \mathrm{mg} / \mathrm{ml}$ sebesar 7,33 mm, sedangkan untuk kontrol negatif (pelarut etanol) tidak menunjukkan daya hambat terhadap pertumbuhan S. typhi. Jika dibandingkan 
dengan obat antibiotik (tetracycline) sebagai kontrol positif yang memiliki daya hambat sebesar $25 \mathrm{~mm}$, maka seluruh konsentrasi ekstrak etanol kulit batang $E$. zwageri mempunyai daya hambat yang lebih rendah.

Konsentrasi 1, 5, 10 dan $15 \mathrm{mg} / \mathrm{ml}$, serta kontrol positif memberikan pengaruh yang signifikan atau berbeda nyata dibandingkan dengan kontrol negatif dalam menghambat pertumbuhan S. typhi. Hasil respon hambatan pada zona hambat pertumbuhan S. typhi menunjukkan bahwa konsentrasi 10 dan $15 \mathrm{mg} / \mathrm{ml}$ memiliki respon hambatan kuat dan pada konsentrasi 1 dan $5 \mathrm{mg} / \mathrm{ml}$ memiliki respon hambatan sedang. Level konsentrasi optimum ekstrak kulit batang E. zwageri adalah yang memiliki respon hambatan kuat terhadap pertumbuhan S.typhi yaitu pada konsentrasi 10 dan 15 $\mathrm{mg} / \mathrm{ml}$. Namun hasil ini masih lebih rendah jika dibandingkan dengan antibiotik (tetracycline) yang memiliki respon hambatan sangat kuat dalam menghambat pertumbuhan S.typhi.

Ekstrak kulit batang E. zwageri mengandung golongan senyawa berupa alkaloid, flavonoid, terpenoid, fenolik, tanin, dan saponin. Diduga senyawasenyawa tersebut menyebabkan penghambatan terhadap pertumbuhan $E$. coli dan S. typhi. Struktur dinding sel sel bakteri E. coli dan S. typhi tersusun atas peptidoglikan, lipoprotein dan membran luar fosfolipid yang mengandung lipopolisakarida. Membran sel berfungsi sebagai pembungkus sel yang berada diluar membran sitoplasma dan perubahan-perubahan tekanan osmotik yang terjadi akan dilindungi oleh lapisan ini (Johnson et al. 2011). Terjadinya penghambatan pertumbuhan bakteri disebabkan oleh kontak senyawa yang terdapat dalam ekstrak yang berdifusi kedalam sel bakteri, dimana beragamnya senyawa yang terdapat dalam ekstrak menyebabkan aktivitas biologisnya juga berbeda-beda (Sumito et al. 2016).

Mekanisme kerja alkaloid, flavonoid, fenolik dan terpenoid ( Robinson, 1995; Cowan, 1999; Anita et al. 2014) yaitu: alkaloid dalam menghambat pertumbuhan bakteri yaitu dengan menghambat pembentukan dinding sel khususnya komponen penyusun peptidoglikan sehingga berdampak pada kematian sel. Flavanoid dapat berikatan dengan protein ekstraseluler membentuk senyawa komplek yang berdampak pada terganggunya integritas dan rusaknya membran sel khususnya pada bagian fosfolipid sehingga permeabilitasnya menjadi menurun. Aktivitas protein (enzim) yang terdapat pada membran sel akan mati akibat adanya senyawa fenol. Terpenoid dapat berikatan dengan protein, karbohidrat dan lipid pada membran sel yang berakibat pada menurun atau hilangnya permeabilitas membran dan pada akhirnya menyebabkan lisis sel.

Tanin memiliki kemampuan dalam mengganggu kerja enzim, adhesin dan pengangkutan protein yang berakibat pada menurunnya permeabilitas dinding sel dan pada akhirnya sel akan mati (Cowan, 1999; Nurviana, 2016). Aktivitas saponin dalam menghambat pertumbuhan bakteri yaitu dengan mengganggu kerja enzim dan merusak membrane sitoplasma yang berakibat pada terhambatnya transport nutrisi yang pada akhirnya menyebabkan 
kematian bakteri (Robinson, 1995; Dasopang, 2017)

\section{Kesimpulan}

Rendemen ekstrak kulit batang $E$. zwageri sebesar 21,63\% (kadar air 7,6\%). Kulit batang E.zwageri mengandung golongan senyawa bioaktif berupa alkaloid, flavonoid, terpenoid, fenolik, tanin, dan saponin. Ekstrak kulit batang $E$. zwageri memiliki aktivitas antibakteri terhadap E. coli dan S. typhi. Konsentrasi optimum dalam menghambat pertumbuhan E. coli pada level $200 \mathrm{mg} / \mathrm{ml}$ dengan kategori respon hambatan sangat kuat, sedangkan konsentrasi optimum dalam menghambat pertumbuhan $S$. typhi pada level $15 \mathrm{mg} / \mathrm{ml}$ dengan respon hambatan kuat.

\section{Saran}

Perlu dilakukannya penelitian lanjutan terkait penentuan nilai MIC (minimum inhibitory concentration) dan $\mathrm{MBC}$ (minimum bactericidal concentration) dari ekstrak kulit batang E. zwageri terhadap pertumbuhan E. coli dan S. typhi. Selain itu perlu dilakukannya isolasi dan identifikasi senyawa tunggal yang bersifat sebagai antibakteri.

\section{DAFTAR PUSTAKA}

[Anonim]. 1976. Vademikum Kehutanan Indonesia. Departemen Pertanian Direktorat Jendral Kehutanan. Jakarta.

Anita A, Khotimah S, Yanti AH. 2014. Aktivitas Antibakteri Ekstrak Daun Benalu Jambu Air (Dendropthoe pentandra L. Miq). JProtobiont. 3(2):268-272.

Cowan, M.M. Plant Products as Antimicrobial Agents. Clinical Microbiology Reviews. 1999; 12: 564-582.
Darussalam H. 2016. Uji Sensitivitas Ekstrak Kayu Ulin (Eusideroxylon zwageri) Terhadap Pertumbuhan Bakteri Staphylococcus aureus Secara In Vitro.Mahakam Med Lab Tech J. 1(2):81-90.

Dasopang ES. 2017. Skrining Fitokimia dan Uji Aktivitas Antibakteri Ekstrak Etanol Daun Sangitan (Sambucus javanica Reinw) terhadap Pertumbuhan Bakteri Escherichia coli dan Salmonella thypi. J Bio Lingkungan, Industri, Kesehatan. 4(1):54-62.

Filho M. $2006 . \quad$ Bioactive Phytocompounds: New Approaches in the Phytosciences. Dalam Modern Phytomedicine. Iqbal Ahmad, Farrukh Aqil dan Mohammad Owais (Ed) WileyVCH. Germany.

Harbone JB. 1996. Metode Fitokimia: Penuntun Cara Modern Menganalisis Tumbuhan, Ed ke-2, Penerjemah Kosasih Padmawinata dan Iwang Soediro. Bandung. ITB.

Haygreen JG dan JL Bowyer. 1996. Hasil Hutan dan Ilmu Kayu, Suatu Pengantar (Terjemahan Sutjipto, AH). Gadjah Mada University Press. Yogyakarta.

Heyne K. 1987. Tumbuhan Berguna Indonesia. Jilid 1. Yayasan Sarana Wana Jaya. Jakarta

Houghton PJ dan Raman A. 1998. Laboratory Handbook for the Fractionation of Natural Extracts. Chapman and Hall. London.

Johnson AG, Ziegler RJ, Hawley L. 2011.Essential Mikrobiologi dan Imunologi. Ed ke-5. Surjawidjaja JE, penerjemah; Saputra L, editor.Tangerang: Binarupa Aksara.

Kemenkes RI. 2011. Buletin Jendela Data dan Informasi Kesehatan. Jakarta. Kementerian Kesehatan Republik Indonesia. 2(2):1-3. 
Mailuhu M, Runtuwene MRJ, Koleangan HSJ. 2017. Skrinning Fitokimia dan Aktivitas Antioksidan Ekstrak Metanol Kulit Batang Soyogik (Saurauia bracteosa).Chem.Prog. 10(1):1-7.

Manuhuwa E. 2007. Kadar Air dan Berat Jenis pada Posisi Aksial dan Radial Kayu Sukun (Arthocarpus communis, J.R dan G. Frest). J Agroforestri. 2(1):49-55.

Mariani Y, Yusro F, Konishi Y, Taguchi T, Tominaga A. 2016. Regulatory effects of five medicinal plants used by Dayak Uud Danum in West Kalimantan Indonesia on the delayed type hypersensitivity and the inflammation of human colon epithelial cells. Kuroshio Science., 10:59-71.

Nurviana V. 2016. Skrining Fitokimia dan Uji Aktivitas Antibakteri Ekstrak Etanol Kernel Biji Buah Bacang (Mangifera foetida L) terhadap Escherichia coli. J Sains dan Ilmu Farmasi. 1(2):66-74.

Pelczar MJJr dan Chan ECS. 2005. DasarDasar Mikrobiologi. Volume ke-1. Hadioetomo RS, Imas T, Tjitrosomo SS, Angka SL, penerjemah. Elements of microbiology. Jakarta: UI Press.

Pratiwi SUT. 2008. Mikrobiologi Farmasi. Yogyakarta: Penerbit Erlangga.

Rahmah SH, Suharti, Subandi. 2014. Uji Antibakteri dan Daya Inhibisi Ekstrak Kulit Manggis (Garcinia Mangostana L.) terhadap Aktivitas Xantin Oksidase yang Diisolasi dari Air Susu Segar Sapi. JOM Bidang Kimia UM. 2(2):1-11.

Robinson, T. 1995. Kandungan Organik Tumbuhan Tingkat Tinggi. Penerbit ITB. Bandung. Hal. 36-45.
Sari RP, Roza RM, Fitmawati. 2015. Aktivitas Antibakteri Ekstrak Daun Mahang (Macaranga triloba (Muell.) Arg.) Terhadap Escherichia coli dan Salmonella typhi. JOM FMIPA UNRI. 2(2)1-8.

Sjostrom E. 1995. Kimia Kayu, DasarDasar dan Penggunaannya. Ed ke2. Cetakan pertama. Sastrohamidjojo H, Prawirohatmodjo S, penerjemah. Wood Chemistry, Fundamentals and Application. Yogyakarta: Gadjah Mada University Press.

Sumito RJ, Khotimah S, Linda R. 2016. Uji Bioktivitas Fraksi Metanol dan Etil Asetat Tumbuhan Paku Sisik Naga (Drymoglossum piloselloides (L) pressl.) terhadap bakteri Staphylococcus aureus dan Salmonella typhi. J Protobiont. 5(1): 30-38.

Wasito H. 2011. Obat Tradisional Kekayaan Indonesia. Ed ke-1. Cetakan pertama. Yogyakarta: Graha Ilmu.

WHO. 2009. Recommendation on global use of rotavirus vaccine. Weekly Epidemiological record, no 23.

Yusro F. 2010. Rendemen Ekstrak Etanol dan Uji Fitokimia Tiga Jenis Tumbuhan Obat Kalimantan Barat. J Tengkawang. 4(2): 29-36.

Yusro F, Diba F, Mariani Y, Etis EP, Leonardo, Randi A. 2013. Ragam Tumbuhan Berkhasiat Obat di Kalimantan Barat. Jilid 1. Pontianak: FU Press.

Yusro F, Diba F, Mariani Y, Etis EP, Leonardo, Randi A. 2014. Ragam Tumbuhan Berkhasiat Obat di Kalimantan Barat. Jilid 2. Pontianak: FU Press. 